Anna Szymoszyn

ORCID: https://orcid.org/0000-0002-0014-8123

Instytut Archeologii i Etnologii / Poznań

Polska Akademia Nauk

\title{
Polacy w Berlinie i Londynie: różne oblicza sukcesu migracyjnego. Część 2
}

\author{
Poles in Berlin and London: different faces of migration \\ success. Part 2
}

\begin{abstract}
The article, presenting the emic approach, concerns Polish migrants settling in Berlin and London, who coped with the integration process and achieved personal success on various levels. It is the second part of the whole cycle, started with the text of Agnieszka Szczepaniak-Kroll, Poles in Berlin and London: different faces of migration success. Part 1 (published in the same issue of JUE). Both are based on grant research and focus particularly on the post-accession period. The article analyses ways and strategies that caused Poles to achieve a successful existence in a new country of settlement, to meet their needs of well-being and happiness in their familial, professional and social lives. Differences and similarities in the understanding of success by migrants and strategies for achieving it were investigated. This helped to create a holistic picture of the successful and satisfactory integration of migrants, as well as a picture of their perception of success.
\end{abstract}

Keywords: Poles, Berlin, London, migration, success, integration, well-being, migration strategies, emic approach.

Artykuł dotyczy polskich migrantów osiadłych w Berlinie i Londynie, którzy poradzili sobie z procesem integracji i odnieśli osobisty sukces na różnych płaszczyznach. Prezentuje emiczne podejście do tematu. Stanowi drugą część z tworzącego całość cyklu, rozpoczętego tekstem Polacy w Berlinie i Londynie: różne oblicza sukcesu migracyjnego. Częś́ 1 autorstwa Agnieszki Szczepaniak-Kroll (zamieszczonego w tym samym tomie JUE). Obydwa bazują na badaniach grantowych, szczególnie koncentrując się na okresie poakcesyjnym. W artykule przeanalizowane zostały sposoby i strategie prowadzące Polaków do udanego życia w nowym kraju osiedlenia oraz do zaspokojenia ich potrzeby dobrostanu i szczęścia, zarówno rodzinnego, jak 
i zawodowego oraz społecznego. Prześledzono różnice i podobieństwa w pojmowaniu sukcesu przez migrantów oraz strategie jego osiągania za granicą. W ten sposób powstał całościowy obraz zjawiska pomyślnej, satysfakcjonującej integracji migrantów, jak również postrzegania przez nich sukcesu.

Słowa klucze: Polacy, Berlin, Londyn, migracja, sukces, integracja, dobrostan, strategie migracyjne, emic.

Odebrano / Received: 31.01.2020

Zaakceptowano / Accepted: 20.05.2020

Jak zostało zaprezentowane w pierwszej części tego cyklu, nasze badania mieszczą się w szeroko pojętej antropologii miasta. Dotyczą bowiem wybranej grupy migrantów zamieszkujących tylko i wyłącznie duże aglomeracje miejskie w Europie Zachodniej, charakteryzujące się multikulturowością, multinarodowością, otwartością na przybyszów. Ci zaś rozwijają prężnie nowe miejsce zamieszkania, mimo że zderzają się z głęboko odmiennym środowiskiem społecznym i kulturowym. Właśnie tutaj istnieją największe możliwości osiągnięcia sukcesu. Sprzyjają temu wciąż rozwijające się miejsca pracy, wielki kapitał, przyjazna polityka dla małych firm i tych, którzy zamierzają otworzyć swój biznes, także stabilność zasad i równość w relacjach pracowniczych. Mieszkańcy mają nieograniczony dostęp do dóbr kultury, nauki, klubów sportowych. Wielkie miasto to liczne i różnorodne połączenia komunikacyjne regionalne i globalne. Ważne jest uregulowane i stabilne prawo, transparentność, czytelna polityka migracyjna ${ }^{1}$, wreszcie powszechne odczuwanie nieograniczonych możliwości.

Spójrzmy chociażby na Londyn, który jest drugim najważniejszym centrum biznesowym świata, tętniącym życiem tysięcy firm, banków, centrów handlowych i kulinarnych, kulturalnych, sportowych, wielu uniwersytetów i szkół. To właśnie tutaj powstała w latach 70. XX wieku idea Open University, która upowszechniła się i rozrosła, dając możliwość kształcenia się nie tylko rdzennym mieszkańcom wysp, ale wszystkim chętnym migrantom, którzy pragną podwyższać swoje kwalifikacje. Stopa bezrobocia regularnie spada od ponad dekady, a liczba zatrudnionych rośnie, przy równoczesnym stałym poziomie samozatrudnionych, co oznacza, że samorząd miejski, państwo i korporacje inwestują w otwieranie nowych miejsc pracy. O rozwoju miasta, coraz bardziej atrakcyjnego dla młodych ludzi, świadczy fakt, że pomiędzy 2005 a 2015 rokiem regularnie rósł odsetek osób między 25 a 64 rokiem życia $z$ wyższym wykształceniem i kwalifikacjami specjalistycznymi (z ok. 28\% w 2005 do ok. 60\% w 2015)². Te dane pokazują również, że w okresie największej fali migracji z nowoprzyjętych krajów Unii Europejskiej do Londynu wyraźnie zaznaczała się grupa ludzi z wyższym wykształceniem lub chętnych

\footnotetext{
1 Por. Mayor of London 2010.

2 London Datastore, 04.05.2020.
} 
do kontynuowania edukacji w Anglii. W 2018 roku populacja miasta wynosiła ponad 8904 tysięcy osób, czyli była 6\% wyższa, niż 5 lat wcześniej³

Dlatego właśnie wielkie miasta stały się polem naszych badań etnograficznych. Badaliśmy, jak polscy mieszkańcy poradzili sobie i nadal radzą w zróżnicowanym otoczeniu wielkomiejskim, jakie podejmują wyzwania, na ile głęboko się integrują i czy miasto pomaga im znaleźć swoją drogę do sukcesu i szczęścia. W artykule zaprezentowana została część wyników badań realizowanych w dwóch aglomeracjach miejskich: berlińskiej i londyńskiej. Jest on drugą częścią z dwóch, tworzących całość. W pierwszej z nich Polacy w Berlinie i Londynie: różne oblicza sukcesu migracyjnego. Część 1, autorstwa Agnieszki Szczepaniak-Kroll, przedstawiono założenia badawcze, na których oparte były prowadzone studia oraz wyciągane na ich podstawie wnioski. Omówiono także specyfikę Berlina i Londynu oraz na tym tle specyfikę polskiej grupy migrantów. W przedkładanym tekście koncentruję się głównie na źródłach wywołanych - wywiadach, ze względu na ich najbardziej osobisty, zindywidualizowany charakter, oddający istotę postawionego problemu. Poruszam również zagadnienie rozumienia takich pojęć, jak dobrostan i sukces, które były omówione w części pierwszej cyklu, gdyż bezpośrednio do nich odnoszą się nasi rozmówcy.

W badaniach, jak już wspomniała Agnieszka Szczepaniak-Kroll, przyjęto założenie, że sukces ujmowany jest nie tylko w wymiarach ekonomicznych, ale przede wszystkim społecznych i kulturowych. Za ludzi odnoszących powodzenie uznani zostali ci, którzy sami tak się postrzegają, jak i ci, którzy za takich są uważani. W artykule analizuję owe indywidualne strategie migracyjne, które przyczyniają się do osiągnięcia osobistego sukcesu. Skupiam się na tym, jak sami rozmówcy postrzegają go na emigracji i jakimi drogami do niego dochodzą. Zastosowanie zróżnicowanego, jakościowego podejścia do respondentów daje nam tym samym możliwość poznania charakterystycznej dla współczesnego obrazu polskich imigrantów różnorodności motywów, strategii i celów, które przyczyniły się do poczucia dobrostanu i/lub sukcesu życiowego.

Wywiady i obserwacje wskazują, że choć niektórzy respondenci sukces pojmowali w kategoriach powszechnie przyjętych (wysoka pozycja społeczna, wysoki status finansowy, niekiedy rozpoznawalność lub sława), równocześnie upatrywali go w elementach nieco mniej oczywistych. Wymieniali wiele innych „czynników składowych” sukcesu. Wskazywali na to, że są pełnoprawnymi mieszkańcami miasta, mającymi głos, te same prawa, obowiązki i przywileje, co pozostali mieszkańcy - obywatele niemieccy w Berlinie czy brytyjscy w Londynie. Podkreślali swoje zadowolenie z kondycji zdrowotnej i służby zdrowia oferującej usługi medyczne na wysokim poziomie oraz szybką do nich dostępność. Zwracali uwagę na możliwości kształcenia dzieci oraz szereg zabezpieczeń socjalnych. Tak jak założyłyśmy na początku projektu, sukces był przez rozmówców często odczuwany jako fakt prawidłowo przebiegającego procesu integracji. Uznawali za niego

3 London Datastore, 04.05.2020. 
przede wszystkim stabilizację, osiagnnięcie długotrwałego i stałego dobrostanu (well-being), poczucia bezpieczeństwa i zabezpieczenia na przyszłość dla siebie i dzieci, także poczucie wolności i różnorakich możliwości wyboru. To przekonanie miało swoje konsekwencje - wpływało na podejmowanie poważnych decyzji o dalszej osobistej przyszłości i przyszłości rodziny.

W tym miejscu należy zastanowić się, na ile wypowiedzi rozmówców pokrywały się z naukowym rozumieniem integralnych części sukcesu, jakimi są dobrostan i szczęście (well-being, good life, happiness). Elementy, które od razu ujawniają się w postrzeganiu rozmówców, czym jest dobre życie, to satysfakcja zawodowa i finansowa oraz prestiż społeczny. Można by oczekiwać, że migranci ekonomiczni odczują wzrost szczęścia, żyjąc w bogatszych krajach, gdzie mogą szybko poprawić swoją sytuację finansową. Jednak, jak zauważa David Bartram, z perspektywy szczęścia tak motywowana migracja może być błędnym przedsięwzięciem ${ }^{4}$. Ogólnie rzecz biorąc, ludzie nie zyskują szczęścia tylko i wyłącznie dzięki wyższym dochodom. W rozmowach z Polakami mieszkającymi poza krajem rodzinnym, szybko do głosu dochodzą także inne, równie ważne komponenty idei „dobrego życia”. Podążając za Edwardem Fischerem ${ }^{5}$ rozumiemy je jako umiejętność konstruowania takiego życia, które się ceni, postrzega się jako wartościowe. To znów pociąga za sobą poczucie satysfakcji $\mathrm{z}$ własnego losu zgodnego $\mathrm{z}$ wyobrażonymi oczekiwaniami. Poczucie, że się ma taką moc decyzyjną na kształt własnego życia ${ }^{6}$ jest podstawowym elementem rozumienia subiektywnie odbieranego dobrostanu. Zgadza się to z poglądami naszych rozmówców.

$\mathrm{Z}$ ich wypowiedzi wynika, że niemal jednomyślnie postrzegają dobre życie jako możliwość realizacji marzeń i ambicji. W rozumieniu Orvara Lofgrena ${ }^{7}$ dobrostan poszerza się poprzez możliwość organizacji czasu wolnego i swobodnego podróżowania po świecie. W kulturze Zachodu świat turystyki stał się nierozerwalną częścią wyobrażonego „dobrego życia”. Wynika to z popularnego postrzegania antynomii między czasem wolnym a pracą jako „czasem nie-wolnym”. „Nie-wypoczynek” oznacza w takim rozumieniu znój życia, stanowiący powinność jednostki bądź przeszkodę między nią a osiągnięciem „dobrego życia”, rozumianego przede wszystkim jako dziedzina indywidualnej wolności ${ }^{8}$. Dobrostan więc zawiera w sobie ideę wolności, a możliwość jej realizacji daje poczucie „dobrego życia”.

Dobrostan rozumiany jest w literaturze także jako umiejętność zharmonizowania życia zawodowego i rodzinnego, niwelowanie napięć pomiędzy nimi ${ }^{9}$. Warty odno-

\footnotetext{
4 Zob. Bartram 2013, s. 156-175.

5 Zob. Fischer 2014, s. 2.

6 Zob. Fischer 2014, s. 2.

7 Zob. Lofgren 2002.

8 Zob. Horolets 2018, s. 119.

9 Zob. Horolets 2018, s. 126.
} 
towania jest również kolejny element budujący poczucie dobrostanu związany ze sferą życia prywatnego, który zauważyła Anna Horolets ${ }^{10}$. Chodzi o przekonanie migrantów o ich realnym wpływie na osobiste „budowanie rodziny”, na kierunek, w którym „prowadzona jest rodzina" (doing family). Widoczne jest to szczególnie w kontekście transnarodowości, a ona dotyczy niemal wszystkich naszych respondentów. Zatem rodzina, zarówno jako idea, jak i realna grupa ludzi, jest nierozerwalną częścią konceptu dobrostanu. Potwierdzają to nie tylko nasze obserwacje, ale także inni badacze zajmujący się migrantami ${ }^{11}$. Także poczucie zintegrowania się ze społeczeństwem przyjmującym i przyswojenie kompetencji kulturowych są ważną częścią odczuwania dobrostanu. Idea dobrego życia i wyobrażenie, jak je osiągnąć, towarzyszy cały czas migrantom, gdyż jest podstawowym motorem działań osób podejmujących decyzję o wyjeździe oraz w długotrwającym, na ogół przez całe życie, procesie migracyjnym. Sukces migracyjny wiąże się więc nierozerwalnie z ideą „dobrego życia” i odczuwaniem dobrostanu.

W wymiarze materialnym sukces był postrzegany przez rozmówców wielorako ${ }^{12}$. Branże, w których zbadani przez nas polscy migranci odnieśli wymierny sukces na miarę światową, to przede wszystkim zarządzanie, finanse, nauka, medycyna, budownictwo i zawody artystyczne. Jednak, tylko kilkoro respondentów w Londynie rozumiało sukces jako doniosłe osiągnięcie o szerokim zasięgu. Byli wśród nich między innymi: główna architekt w renomowanej firmie budowlanej na rynku międzynarodowym, artysta oraz dyrektorka w jednej z największych na świecie korporacji finansowych. Uważała ona, że tego rodzaju osiągnięcie wymaga pełnego zaangażowania. "Jak się coś robi, to na 100\%” (R4_2015_Londyn). Kobieta była przekonana o tym, że odniosła ponadprzeciętny sukces na miarę światową. By to udowodnić, przedstawiła swoją indywidualną drogę do niego. Stanowiła ona niemalże spełnienie American dream: rozmówczyni pochodziła ze wsi, należała do najlepszych uczennic w kolejnych szkołach, a potem wśród studentów w Warszawie. Podkreślała, że oprócz inteligencji, cechowała ją pracowitość i chęć poszerzania wiedzy. Już na studiach wygrała zagraniczny staż w Belgii, co otworzyło jej drzwi do światowej kariery. Praca stała się dla niej najważniejsza. Za sukces uznała to, że jest jedyną kobietą na tak wysokim szczeblu w swej korporacji i do tego Polką, a nie Brytyjką z wyższych sfer. Elementem dumy był więc dla niej rodzaj awansu społecznego, który odniosła. Ta respondentka i wielu innych rozmówców podkreślało równocześnie, że w świecie biznesu i sztuki międzynarodowej pochodzenie odgrywa podrzędne znaczenie. Liczy się wykształcenie, doświadczenie zawodowe, kompetencje, wybitny talent oraz często - co szczególnie ciekawe - urok osobisty bądź charyzma. To, że jako Polacy odnieśli sukces, było jednak ważne dla nich samych.

\footnotetext{
${ }^{10}$ Horolets 2018, s. 131.

${ }^{11}$ Horolets 2018.

${ }^{12}$ Próby ujęcia pomiaru sukcesu - zob. Sobczyk 2009.
} 
W wypowiedziach berlińskich respondentów dały się uwidocznić dwa główne sposoby postrzegania sukcesu w życiu na emigracji. Dla kilku interlokutorów, będących w zdecydowanej mniejszości, jawił się on jako coś spektakularnego, wybitnego, dzieło, które wieńczy działania w określonej, wymagającej szczególnych kompetencji dziedzinie. Jeden z nich, pracownik mediów, mówił:

Ja nie rozważałbym swojego życia tutaj jako sukcesu [...]. Nie ma niczego w moim pojęciu bardzo wyjątkowego w tej drodze, którą ja osobiście gdzieś tam obrałem i którą tu realizuję [...]. Dla mnie sukces to jest ten moment, kiedy nie to występuje, co ma ciągłość i jest normalnym życiem zawodowym, sukcesem może być pozytywne zakończenie jakiegoś projektu, czegoś odrębnego, czegoś unikalnego (M1_Berlin $\left.{ }^{13}\right)$.

W opinii cytowanego mężczyzny sukces można było osiągnąć jedynie w wybranych, najbardziej prestiżowych profesjach związanych na przykład z biznesem, nauką czy sztuką. Często wiązał się on z popularnością, podziwem i chęcią naśladowania przez innych. W tym ujęciu odpowiadał definicji, iż sukces to wynik realizacji określonego typu zadania unikalnego, ocenianego pozytywnie ze względu na swoją doniosłośćc ${ }^{14}$. Zgodnie z tymi założeniami, należy go zatem rozpatrywać jako osiągnięcie wyjątkowe, rezultat wysokich kompetencji i szczególnego wysiłku. Podzielający to zdanie Polacy z Berlina (dwóch lekarzy prowadzących własne praktyki i znany pracownik mediów) nie uznawali się zatem za „ludzi sukcesu”, pomimo że z pozycji zewnętrznego obserwatora do takich należeli. Byli jednak w mniejszości.

Zdecydowana większość respondentów nie widziała konieczności spełniania aż tak wysokich kryteriów, jak wspomniani berlińscy i londyńscy respondenci. Rozmówcy byli bliscy definicji sukcesu zawartej w Stowniku jezzyka polskiego, mówiącej o tym, że jest to pomyślny wynik jakiegoś przedsięwzięcia, osiągnięcie zamierzonego celu, choć może (ale nie musi) wiązać się również ze zdobyciem sławy, majątku, wysokiej pozycji itp ${ }^{15}$. Sukces oznaczał zatem szerszą kategorię, nie zarezerwowaną „dla wybranych”.

$Z$ rozmów wynikało, że każdy człowiek postrzega swój osobisty sukces w odrębny sposób, w zależności od przyjętych indywidualnych kryteriów. Ponadto zakres tego pojęcia zmieniał się w czasie oraz w zależności od okoliczności.

Wydaje mi się, że to bardzo abstrakcyjne pojęcie, które może się zmieniać w bardzo dużej zależności jak o sobie myślimy, skąd jesteśmy, w jakim wieku, może także jakiej jesteśmy płci i co taka osoba sobie zamierzyła, co chciała osiągnąć (K1_Berlin).

\footnotetext{
${ }^{13}$ Dane respondentów zostały zakodowane zgodnie z Ustawą o Ochronie Danych Osobowych. Wywiady, nagrane i transkrybowane, przechowywane są w Archiwum Pracowni Etnologii IAE PAN w Poznaniu.

${ }^{14}$ Doroszewski 2016, s. 86.

${ }^{15}$ Doroszewski 2016.
} 
Respondentka $\mathrm{z}$ Londynu, pracująca $\mathrm{w}$ jednej z korporacji kinowych, działająca aktywnie w brytyjskich związkach zawodowych, w rozmowie o sukcesie migracyjnym w rozumieniu szczęścia, osobistego rozwoju i zadomowienia, zauważyła, że:

Konkretnie, bez lawirowania, jestem teraz [w Londynie $\left.{ }^{16}\right]$ dużo bardziej pewniejsza siebie i moja niska samoocena [sprzed wyjazdu z Polski] jest teraz wyższa. To wynika też z tego, że jestem starsza (...) i że przestałam mieć problem z tym, że »O boże, pracuję tylko w kinie!« Jakby tylko przez ten pryzmat oceniałam wcześniej samą siebie. A teraz nie ma w tym nic złego, trudno, mogę szukać innej pracy. Nauczyłam się być w porządku ze sobą (R1_2017_Londyn).

Respondent, który wyjechał jako dziecko w czasach komunizmu, konstatował:

Powodem decyzji moich rodziców o wyjeździe z Polski było to oczekiwanie tego, co oni nazwali normalnym życiem, ale z perspektywy Polski to był sukces w sensie ekonomicznym, bo sukcesem była możliwość prowadzenia zwykłego życia bez tych ograniczeń PRL-owskich wtedy jeszcze, czy też od razu stanu wojennego, bo było akurat tuż przed (M1_Berlin).

Także Polka mieszkająca w aglomeracji londyńskiej od 1980 roku wspominała o życiu w Anglii jako dobrym, pełnym uroków, w którym można było szybko realizować swoje marzenia:

Dostałam szybko paszport, wizę i pozwolenie na pracę, bo miałam wujka w Londynie, który został w Anglii po wojnie. Poprosiłam go, żeby mi pomógł załatwić pracę u siebie w hotelu. Bo ja w Polsce zdawałam na etnografię, ale się nie dostałam, więc studiowałam w studium turystyczno-hotelarskim. Chodziłam tam przez dwa lata i stąd ten pomysł, żeby skontaktować się z wujkiem, który w Anglii prowadził hotel. Wtedy myślałam, że będę jaką̧́ karierę w hotelarstwie robiła. Więc chciałam połączyć naukę praktyki z nauką angielskiego. O pozwolenie na pracę aplikowałam jeszcze z Polski. Bardzo trudno było w tamtym czasie zdobyć takie coś. Ja czekałam pół roku i dostałam. To był mój pierwszy sukces (śmiech). Przypuszczam, że mnie pomogło to, że studiowałam hotelarstwo i napisałam, że chcę zdobyć praktykę zawodu. Wujek był zdziwiony, że tak szybko dostałam. Ja od razu jechałam do pracy. Pamiętam, że przyjechałam w piątek, a w poniedziałek już szłam do pracy. (...) Mama nie namawiała mnie do powrotu. Widziała, że mi się tu układa, że daję sobie radę, że jestem szczęśliwa. Wszystko było O.K. Fajne było życie. Widziała, ile ja rzeczy robię, ile ja jeżdżę, zwiedzam, oglądam. Wszędzie jeździłam. Byłam wszędzie. (...)

${ }^{16}$ Uwagi w kwadratowych nawiasach, znajdujące się w cytatach w całym artykule, są dopowiedzeniami osoby prowadzącej wywiad. 
Na wszystko było nas stać. Mogłam sobie i na to pozwolić i na to... Byłam otoczona fajnymi ludźmi (...).Widziałam każdy musical na Westendzie, byłam na każdym koncercie. (...) Musiałam wszystko chłonąć, zobaczyć, mieć wszystko w pamięci i przeżywać później na nowo (R8_2015_Londyn).

Dla emigrantów w latach 80. sukcesem był już sam wyjazd za granicę wobec mnożonych przez polskie władze trudności paszportowych. Kolejny sukces stanowiło zalegalizowanie pobytu, którego długość z kolei lokalne władze starały się jak najbardziej ograniczać. Dziś poprzeczka ustawiona jest o wiele wyżej.

Większość respondentów z Berlina dostrzegało dwa wymiary sukcesu, zawodowy i prywatny, które wzajemnie się uzupełniały:

Najczęściej sukces kojarzy się z finansową stroną tego medalu, ale ja bym też to widział jako... nie wiem, rodzinę, miejsce w społeczeństwie, $\mathrm{w}$ środowisku, zadowolenie $\mathrm{z}$ tego co się robi, między innymi też sukces jakiś materialny typu dom, firma. (...) To jest całokształt jakiś, a nie tylko wyrwany element tego wszystkiego (M2_Berlin).

Ja myślę, że to jest spełnienie jakiegoś marzenia, to jest osiągnięcie celu, który ktoś sobie postawił (...) niekoniecznie rozchodzi się o pieniądze, czy jakieś kwestie materialne (...), ale o osiąnnięcie swoich celów, które mogą być, w zależności w jakiej pozycji, powiedzmy, ktoś startuje, bardzo różne (K1_Berlin).

Dla mnie sukces to chyba to, że mam żonę, dwójkę dzieci i wszyscy jesteśmy szczęśliwi i powiedzmy stać nas na urlop, na samochód, na jakieś tam dogodności typu, że możemy sobie w weekend gdzieś wyjechać i pobyć razem itd. To chyba sukces, że nie musimy sobie odmawiać tak jakoś strasznie. Jak chcemy iść na lody, to idziemy na lody, jak chcemy iść na pizzę, to idziemy na pizzę, chcemy coś zjeść w domu, to jemy w domu i dzieci chcą jaką́s zabawkę..., po prostu nie musimy się zastanawiać, czy bułki czy zabawki, tak jak nasi rodzice się zastanawiali w latach osiemdziesiątych, dziewięćdziesiątych (M3_Berlin).

Dla odmiany większość londyńskich respondentów koncentrowało się na finansowych aspektach sukcesu. Wyraźnie dobre i stałe zarobki stanowiły najważniejszy czynnik przyciągający oraz środek do osiągnięcia własnych celów, oznaczały bowiem dobrostan, stabilizację, poczucie wolności i możliwości wyboru. Nie znaczy to, że nie liczył się aspekt prywatny. Także te dwie sfery musiały być komplementarne. Bardziej akcentowano jednak elementy materialne.

Przedstawiciel fali migracyjnej przybyłej do Londynu w latach 90. XX wieku, respondent pracujący w branży kosmetycznej (R1_2015_Londyn), sukces upatrywał $\mathrm{w}$ spełnieniu zawodowym, będącym rezultatem wspinania się po drabinie awansu. Wskazywał na zadowolenie z zarobków i szacunek, jakim darzono go na równi z innymi 
pracownikami. Na przykładzie swojej kariery pokazywał, czym jest dla niego sukces umiejętnością poruszania się w lokalnym środowisku zawodowym, a co za tym idzie swobodą życia w nowym miejscu:

Dostałem pracę w Chelsea, zawodowo się realizowałem, awansowałem, zacząłem jeszcze lepiej zarabiać. Przeprowadziłem się więc do tego mieszkania ${ }^{17}$. To był mój własny luksus. (...) Mieszkają tu Angielki, z którymi się przyjaźnię. Potem awansowałem w różnych firmach kosmetycznych. (...) Teraz pracuję w Harveys Nicols na Knightsbridge, bardzo ekskluzywnym domu towarowym. (...) Myślę teraz o przejściu do Liberty's, ekskluzywnego domu towarowego - butiku koło Regents Street. (...) W tym środowisku wszyscy się znają. Absolutnie. Mam swoją markę [jako wizażysta], jestem znany, znam tą czy tamtą wizażystkę, robiłem z nią pokaz mody (...) (R1_2015_Londyn).

Jak wynika z wypowiedzi, rozmówca zdawał sobie sprawę, że Anglia umożliwiła mu awans społeczny, którego nie osiągnąłby we własnym kraju. Był świadom granic swoich możliwości, w których poruszanie się było dla niego wystarczająco satysfakcjonujące.

Znów inna respondentka (R12_2015_Londyn) uważała, że dla niej życie w Londynie to osobisty sukces, gdyż wyjechała do Anglii jako „młoda dziewczyna bez studiów i znajomości angielskiego”, głównie po to, by „zobaczyć jak to jest zagranicą”. $\mathrm{Na}$ miejscu odkryła, że bardzo łatwo jest podjąć różnego rodzaju kursy, wykształcić się, znaleźć pracę i awansować.

Coś tam mówiłam po angielsku, ale ja przyjechałam tu jeszcze przed 2004 rokiem. Zapisałam się na kurs, żeby móc przyjechać. Miałam więc wizę i mogłam pracować jako studentka. (...) Zorientowałam się, że jak zrobię jakieś kursy doszkalające, to dostanę awans. I tak robiłam (R12_2015_Londyn).

To była jej droga, jaką obrała do osiągnięcia odpowiedniego standardu życia, satysfakcji, stabilności i poczucia dobrostanu.

W krótkim czasie zaczęłam na tyle dobrze zarabiać, że dużo podróżowałam z koleżankami po świecie. Znajomi z Polski nie mogli zrozumieć, jak ja mogę rzucić robotę na 3 miesiące i wyjechać sobie do Afryki. A ja mogłam. Bo wracałam i od razu dostawałam pracę. Żyłam tak jak chciałam (R12_2015_Londyn).

Rozmówczyni po pewnym czasie awansowała w instytucji miejskiej na wyższe stanowisko, co przełożyło się na podwyższenie i ustabilizowanie standardu życia.

\footnotetext{
${ }^{17}$ W kamienicy w „białej” dzielnicy dla klasy średniej, postrzeganej jako posh.
} 
To moje zainteresowanie kulturami i ludźmi w końcu zamieniłam na pracę. Jestem social worker i mam pod sobą bezdomnych $\mathrm{z}$ centrum miasta. Praca trudna, ale realizuję się w niej (...). Potrzebowali najpierw kogoś ze znajomością polskiego, bo przed wejściem do Unii było sporo Polaków na ulicy. Ale po 2004 roku oni dostali albo pracę, albo zasiłek. Teraz jest więcej Rumunów. Ale z nimi też się dogaduję, bo zawsze ktoś z nich zna francuski albo angielski (R12_2015_Londyn).

Analizując wypowiedzi respondentów z Niemiec i Anglii, zauważamy zatem, że miarą sukcesu zawodowego były:

- awans zawodowy:

Ja nienawidzę sprzątać (śmiech), więc robię coś fajniejszego (K2_Berlin, przedsiębiorczyni).

W Anglii doświadczenie sprawia, że z zasady się awansuje, a jeśli ma się do tego odpowiednie wykształcenie, talent i predyspozycje osobowościowe, kariera murowana (R5_2015_ Londyn).

- satysfakcja z wykonywanej pracy, zwłaszcza u osób z wyższym wykształceniem, pracujących w spełniającym ich wymagania zawodzie:

Ja myślę tak, że dla cudzoziemca mieszkającego w innym kraju sukcesem jest praca w swoim zawodzie [...], to jest jakaś tam miara, że się znalazło miejsce powiedzmy adekwatne do umiejętności (K2_Berlin).

Pewnie gdybym została w Polsce, to życie ułożyłoby mi się zupełnie inaczej. Na pewno nie pracowałabym w takim zawodzie. Wątpię, żebym miała robotę, w której bym się realizowała. A już na pewno nie zarabiałabym tyle, co tutaj. Jak patrzę na moich znajomych z Polski, to oni o wiele ciężej pracują (R12_2015_Londyn).

- prestiż społeczny (choć nie w każdym przypadku) lub choćby akceptacja, poważanie ze strony współpracowników:

Ja uważam [za sukces] takie normalne życie według swoich zasad, że nie trzeba jakoś kosmicznie się naginać, więc to jest sukces na co dzień... (K2_Berlin).

W środowisku rozmawiamy o muzyce, nie o polityce, o tym kto jak zaśpiewał czy zagrał. Każdy wie, że ten jest z Polski, a ktoś tam z Niemiec, ale liczy się jakość pracy i to, że jest się artystą w Wielkiej Brytanii czy Niemczech (R5_2015_Londyn). 
- osiągnięcia finansowe, niekoniecznie ogromne, ale zapewniające życie na godnym poziomie.

Sukces to jest móc robić, co się lubi i jeszcze z tego co się lubi móc normalnie żyć finansowo, to to jest sukces (K3_Berlin).

Ja uważam za sukces, jeżeli człowiek potrafi ze swojej pracy żyć wygodnie (K4_Berlin).

Na początku nie było łatwo. Ale jak się tak wszystko poukłada, to dużo szybciej można zarobić. Pojechaliśmy, żeby podszkolić angielski i zarobić. Chcieliśmy zarobić na mieszkanie. Już po roku pracy kupiliśmy pierwsze, w 2000 roku, w Polsce. Oszczędzaliśmy, ale też korzystaliśmy z życia. Wszystko było w granicach rozsądku. (...) Wkrótce założyłem tutaj własną firmę (...). Zarabiam bardzo dobrze. Po kilku latach kupiłem tutaj mieszkanie. Teraz kolejne... Odłożyliśmy dużo więcej niż bylibyśmy w stanie w Polsce (R9_2015_ Londyn).

Żyjemy tak, jak żyje brytyjska klasa średnia (R5_2015_Londyn).

- osiągnięcia dzieci migrantów:

Córka, która właśnie wyszła za mąż,jest lekarzem pediatrą, to też można powiedzieć sukces; druga menadżerem tutaj w dużej firmie energetycznej i syn też jest lekarzem [...], to też należy do sukcesu... (M2_Berlin).

Mieszkamy w centrum. Tam są bardzo drogie mieszkania. Lubię tą dzielnicę. (...) Czuję się tu dobrze. Przeniosłam dzieci z rejonowej, dużej szkoły, gdzie było dużo dzieci (...), do lepszej, mniejszej szkoły anglikańskiej właśnie w tej dzielnicy. Poziom jest wyższy i chciałam, żeby dzieci miały w szkole Christmas Holiday, a nie tylko Holiday. (...) Ta szkoła jest idealna. Tam są dzieci bankierów, położnych, lekarzy, ludzi biznesu, prawników. Są tu ludzie bardzo profesjonalni zawodowo. To szkoła naprzeciwko Hyde Parku. Jest mało dzieci w klasie (R7_2015_Londyn).

Strasznie szybko stwierdziłam, że: O.K. Ja jestem odpowiedzialna za dzieci, ja nie mogę im pokazać, że jestem smutna, płaczę itd., zrobię wszystko, żeby dzieci mi się nie rozpadły. Bo wie pani, ja zajęta swoimi sprawami, nie dopatrzę czegoś, w domu, w szkole, ich problemów, więc powiedziałam sobie: skupiam się na dzieciach. I to był taki mój cel: muszę wszystko zrobić, żeby one były szczęśliwe, żeby one najmniej ucierpiały i żeby to wszystko jakoś się ułożyło (...). Syn dostał się do elitarnego liceum dla chłopców. Córka też do dobrej szkoły. Oboje studiowali na Cambridge (R8_2015_Londyn). 
Osiągnięcia dzieci były potwierdzeniem dla rodziców, że ich decyzja o emigracji była trafna. Jednocześnie zabezpieczały przyszłość rodziny ${ }^{18}$, także w późniejszych latach.

O ile respondenci w Berlinie rzadko wspominali o przyjaznej polityce edukacyjnej względem dzieci migrantów, o tyle rozmówcy w Londynie często zwracali uwagę na równe traktowanie we wszystkich w szkołach, bez względu na pochodzenie oraz na silny nadzór opieki społecznej nad rodzinami migrantów. W Wielkiej Brytanii warty podkreślenia jest szeroki dostęp do edukacji, kursów i szkoleń także dla dorosłych, o czym mówili respondenci. Fakt ten wpływa na pobudzanie oraz realizację ambicji i planów polskich mieszkańców na wyspach. Dzięki temu, nawet ci z niskim kapitałem społeczno-kulturowym wyniesionym z Polski, mają dużą szansę na podniesienie kwalifikacji, awans zawodowy, społeczny i materialny. W Berlinie natomiast respondenci podkreślali, że w sprawach dbania o przyszłość dzieci radzą sobie sami, udowadniając równocześnie, że są zaradni i samodzielni. Podkreślano, że polskie dzieci dobrze się uczą nie tylko z powodu niższego poziomu nauczania (co powszechnie dostrzegano), lecz wynika to $\mathrm{z}$ wyniesionego $\mathrm{z}$ domu modelu wychowania, w którym edukacja jest niezwykle ważna. Zaważano jednocześnie, że w kraju pochodzenia osiąganie dobrych wyników wymagało często pomocy korepetytorów, a w Niemczech $\mathrm{z}$ powodu lepszej organizacji nauczania nie jest to potrzebne.

Wielu rozmówców zauważyło, że wyznacznikiem sukcesu w Niemczech nie były, aż w tak dużym stopniu, jak w Polsce, warunki finansowe, ze względu na wyższy poziom życia. Natomiast rozmówcy z Anglii często nawiązywali do pieniędzy i zarobków. Podkreślali jednak, że są one ważne o tyle, o ile dają możliwość realizacji innych celów. W obu miastach doceniano wartości niezwiązane z zewnętrznymi materialnymi przejawami dostatku. Łączyły się one $\mathrm{z}$ możliwością realizacji aspiracji, marzeń, a nawet $\mathrm{z}$ uwolnieniem się od presji bogacenia się, odczuwanej w Polsce. Najmłodsi rozmówcy wspominali, że z satysfakcją zrezygnowali za granicą z popularnego w kraju modelu życia „klasy średniej”, obejmującego wieloletni kredyt, dom pod miastem, dwa samochody, inne luksusowe dobra:

W Polsce się wszystko definiuje pod pieniądze, a tutaj nie ma takiego parcia na pieniądze (...).W Polsce definiuje się sukces naprawdę inaczej. (...) Sukcesem jest posiadanie rodziny i zdobywanie majątku, na przykład kupno domu z ogródkiem (...). Ja nigdy nie miałam takich marzeń. W Niemczech definiuje się sukces, jak cię stać na urlop, na taki, jaki chcesz (...). Tak się chyba definiują przez hobby, styl życia, teraz się wszyscy definiują przez jedzenie bio-ekologiczne i chyba przez czas wolny... (K2_Berlin).

Inne kobiety stwierdzily:

\footnotetext{
${ }^{18} \mathrm{Na}$ temat rodzicielstwa migrantów na Wyspach Brytyjskich zob. Brannen et al.2014.
} 
To wszystko zależy jak ktoś definiuje swoje cele życiowe, bo jak mówię o sukcesie to sobie pomyślałam, że z sukcesem kojarzy się od razu dobrobyt normalnie, czyli dom, samochody, nie wiem, wszystko inne, i tym się mierzy człowieka, który osiągnął sukces. Ale to jest chyba kwestia nastawienia, tego, co by w życiu osiągnąć. Nie każdy chce mieć domy, samochody... myślę, że sukces to jest taki kawałek wolności, (...) i mam jeszcze czas wolny dla siebie i nie tylko cały dzień pracuję, to uważam, że to już jest duży sukces...(K3_Berlin).

Ja pochodzę z małego miasta na północnym wschodzie. Ojciec alkoholik i matka uzależniona od niego. Uciekłam na studia do Poznania. (...) [Po studiach] praca kiepska, kiepskie perspektywy. Znajomi pojechali do Londynu. Postanowiłam spróbować. Tak na żywioł, bez planów. (...). Mieszkam od lat w tym mieszkaniu. Lubię je, lubię tą dzielnice, mam blisko park i pracę. Lubię tu żyć. Dobre, różnorodne jedzenie. Jedzenie jest dla mnie ważne. Wszystko jest tu dostępne; w Polsce byłoby drogie, a tu jest relatywnie tanie (...). Podróże. Mogę kilka razy w roku wyjechać z przyjaciółmi na wakacje zagranicę. (...) Ludzie. Każdy jest tu sobą. Mam towarzystwo bardzo różnorodne. (...) W Polsce jest krytyka, a tu można w piżamie pójść do sklepu i nikt na ciebie nie zwróci uwagi. Ludzie tu różnie chodzą ubrani i nikt tego nie komentuje. Ja się tu swobodniej czuję. (...) Moje zarobki jako menadżer na tle brytyjskich kształtują się w dolnych stanach klasy średniej (...), ale nie chciałabym chyba mieszkać gdzie indziej (R3_2015_Londyn).

Miarą sukcesu w życiu prywatnym były natomiast:

- udane życie rodzinne lub towarzyskie,

- poczucie zintegrowania z obecnym środowiskiem,

- poczucie bycia akceptowanym,

- poczucie samoakceptacji,

- zdrowie fizyczne, a w razie jego utraty możliwość korzystania z profesjonalnej opieki zdrowotnej,

- realizacja celów, planów,

- funkcjonowanie w demokratycznym społeczeństwie o ściśle określonych, jasnych regułach.

Warto jednak zaznaczyć różnicę, która ujawniła się między falą migrantów z ostatnich dwóch dekad XX wieku, a migrantami poakcesyjnymi. Ci ostatni to młodzi ludzie, którzy wciąż oceniają swoje życie i pracę poprzez pryzmat zarobków, obowiązków zawodowych do zrealizowania. Natomiast starsze pokolenie migrantów już tego doświadczyło i dziś ceni co innego. Ci ludzie porzucili profesje wymagające poświęcania innych aspektów życia, spełnili swoje podstawowe potrzeby życiowe jak kupno czy długotrwały wynajem mieszkania lub dobrego samochodu. Żyją na satysfakcjonującym poziomie, bez konieczności udowadniania sobie i innym, że mogą więcej. 
W Niemczech najbardziej ceniono stabilizację, spokój, mówiono o braku strachu przed bezrobociem, czy o możliwości utrzymania się w chwili utraty pracy. Wszystkie te elementy składały się na satysfakcję z życia, poczucie szczęścia, spełnienia:

Ogólnie jestem szczęśliwy w życiu i (...) to dla mnie jest sukces. (...). Cieszyć się z tego, co jest i być szczęśliwym w tym, co robię... (M5_Berlin).

Sukces to zależy od nastroju tego dnia, od sytuacji politycznej, od bardzo ważnych rzeczy i od bardzo małych rzeczy i dlatego ja się uważam za człowieka, mogę powiedzieć, sukcesu... nie wiem, przez to, że mi się udaje [w życiu], że prowadzę dobre życie szczęśliwego człowieka (...), to jest pójście drogą, za którą się nie wstydzę, z której jestem dumna, bo to sama osiągnęłam, ale to jest tak niewymierne, co jest dla mnie sukcesem...(K5_Berlin).

Tymczasem w Londynie obraz wyłaniający się $\mathrm{z}$ wypowiedzi respondentów jest bardziej dynamiczny. Młodzi migranci dopiero w dalszej perspektywie życiowej widzą stabilizację domową jako nadrzędną wartość.

Ja z natury wiecznie czuję się w zawieszeniu, nie wiem na pewno, czy to jest moje docelowe miejsce, ale mnie jest tu dobrze. Mieszkam tu już tyle lat... (R3_2015_Londyn).

Nie obawiali się też bezrobocia w tak szybko rozwijającej się aglomeracji. Dla nich wartością było poczucie, że można się realizować według własnego planu. Możliwość życia po swojemu i wtapiania się w lokalny koloryt miasta stanowiły niezaprzeczalne dla nich wartości.

Teraz jestem sobą. Jestem dojrzały. Teraz mogę być poznaniakiem, warszawiakiem, londyńczykiem, Polakiem, Anglikiem, Tybetańczykiem, kim chcę, mogę być. Mogę się utożsamić, stopić niemal z każdą grupą. (...) Mógłbym się zasymilować. Przede wszystkim mogę być sobą (R1_2015_Londyn).

\section{Strategie osiągania sukcesu}

Jak wcześniej wspomniałam, istniały różne podejścia do postrzegania szczęścia i dobrostanu w życiu prywatnym i zawodowym migrantów. Dało się zauważyć, że w opinii migrantów człowiek przebywający na emigracji osiąga sukces, gdy realizują się jego oczekiwania, szczególnie pożądana jest przy tym równowaga między pracą a życiem prywatnym oraz poczucie realizacji siebie i osiągnięcie dobrostanu.

Często spotyka się ludzi, którzy są na tych posadach, a jednocześnie nie są szczęśliwi, więc trudno mówić o sukcesie (K7_Berlin). 
Respondent mieszkający w Londynie od lat 90. XX wieku dostrzegł, że w pierwszym okresie pobytu spokój, radość i równowagę zapewniały mu prawidłowe relacje między pracodawcą a pracownikami oraz godziwe warunki pracy i płacy. Możliwość spełnienia podstawowych potrzeb dawała mu niezbędną równowagę życiową, poczucie stabilizacji i bezpieczeństwa, czego nie odczuwał w Polsce:

Wtedy po prostu cieszyłem się, że w końcu MOGĘ. Ale byłem w miarę rozsądny. Ani specjalnie nie rozrzucałem, ani też nie oszczędzałem. Nie jadłem konserw z chlebem. Jak potrzebowałem zjeść, to zjadłem, potrzebowałem spodni, to kupiłem. Stać mnie było na to, co chcę. Może to nie zabrzmi górnolotnie, ale jedną z największych moich radości była świadomość, że jak coś potrzebuję, to idę i sobie kupuję (...). Ja nie muszę już planować kupna spodni ani butów, tylko kupuję. Samo to poczucie, że jakoś tam jestem zabezpieczony na co najmniej najbliższe pół roku, dawało przekonanie, że jak coś potrzebuję, to nie ma tragedii i można żyć dalej (R 7_2017_Londyn).

Tak przedstawiana droga do sukcesu i jego rozumienie nie były zatem tylko zarezerwowane dla niewielkiej grupy osób. Natomiast ściśle wiązały się z dobrą integracją z miejscowym społeczeństwem oraz podstawowym zabezpieczeniem materialnym.

W trakcie badań udało się wyłonić kilka różnych strategii pobytowych wiodących do sukcesu. Sami respondenci wskazywali, że do jego osiągnięcia niezbędne były:

- ciężka praca: „ciężko trzeba pracować na ten sukces”(K8_Berlin).

- otwarcie na społeczeństwo przyjmujące, przejawiające się w szybkim opanowaniu języka, nawiązywaniu kontaktów z otoczeniem:

Naszła mnie myśl, że siedziałem półtora roku w Londynie, gdzie praktycznie jest wszystko, a ja $z$ tego prawie nic nie skorzystałem, no może byłem w dwóch, trzech muzeach i to wszystko. Postanowiłem więc, że muszę coś bardziej z tego skorzystać, a nie siedzieć w jednym z najbardziej zajętych i zróżnicowanych miast z różnymi jego opcjami i ciekawostkami i nic z tym nie robić (R 7_2017_Londyn).

Jeśli mówimy o sukcesie zawodowym, przede wszystkim wydaje mi się, że chodzi o znalezienie takiej pracy, która daje satysfakcję i pozwala na takie dobre samopoczucie, że robi się coś, co się lubi i jest się w tym dobrym, nadal człowiek ma ochotę się czegoś nauczyć (K7_Berlin).

- rozpoznanie i zaakceptowanie reguł w nim panujących:

Znałem dobrze angielski, (...) rozumiałem [angielskie] klientki, szybko awansowałem w branży (R1_2015_Londyn).

trzeba mieć dobry plan działania (K8_Berlin). 
- odwaga w podejmowaniu decyzji, inwestowaniu w przyszłość:

Znałem dobrze niemiecki, więc załapałem się do niemieckiej firmy turystycznej. Całkiem nieźle zarabiałem no i dużo podróżowałem. (...) Znałem angielski, więc dostałem pracę w londyńskiej filii tej niemieckiej firmy (R2_2015_Londyn).

Ja prawdę mówiąc może byłam odważna, a może naiwna (śmiech). Myślałam, że wszystko będzie wspaniale, super i żadna krzywda mi się nie stanie i wszystko będzie super. To była taka odwaga wieku młodego (śmiech) (R8_2015_Londyn).

Zainwestowałam całe swoje oszczędności, które zaoszczędziłam z mężem w Polsce (K8_Berlin).

Za idealną uważano sytuację, w której możliwe było spełnianie wszystkich lub przynajmniej większości wymienionych warunków:

Trzeba mieć to w głowie, trzeba myśleć, trzeba mieć jakiś plan, który nie zawsze się spełni i trzeba mieć plan B. Jak nie wyjdzie to jedno, to nie trzeba się załamywać, tylko coś jeszcze mieć w zanadrzu. Szczęście trzeba mieć też i jakiś korzystny splot okoliczności, które w danym momencie danej osobie gdzieś tam po drodze umożliwią. Mnie się wydaje, że to jest kilka czynników (K9_Berlin).

Migranci podkreślali, że sukces jest rezultatem procesu, długofalowego działania i nie istnieje jeden wzorzec jego osiągania; każdy wypracowuje własną strategię realizowania potrzeb, oczekiwań, dążeń, ambicji.

Wielu z migrantów, którzy w wieku XX podejmowali działania zmierzające do zrealizowania swoich planów, obecnie ma tego wymierne efekty. Znamienny okazał się rys osobowościowy tych ludzi. Są oni aktywni, uparci w dążeniu do celu, nielękający się niepowodzeń, które w przeszłości niejednokrotnie jeszcze bardziej mobilizowały ich do działania. Co ciekawe, wielu obdarzonych tymi cechami Polaków z powodzeniem realizowało swoje życiowe plany jeszcze przed przyjazdem do Berlina czy Londynu. Wyjazd umożliwił im natomiast szybszy rozwój. Niejednokrotnie kapitał psychologiczny okazywał się ważniejszy od wykształcenia czy posiadanego zawodu.

Wszyscy respondenci byli natomiast zgodni co do tego, że pomimo dobrej strategii, kwalifikacji, umiejętności, nie osiągnęliby sukcesu, gdyby nie korzystny splot różnych sprzyjających im okoliczności, które wydarzyły się w określonym miejscu, czasie i przy udziale różnych osób, czyli jak mówiono: „zwykłe szczęście”. Lekarka stwierdziła:

Myślę, że miałam szczęście, że się tak poukładały sytuacje, że udaje mi się wykonywać ten zawód, a innym nie (K3_Berlin). 
Rozmówcy podkreślali specyfikę Berlina oraz Londynu, jako miast ułatwiających odnoszenie sukcesu (przejawiającego się w awansie społecznym), definiowanego nie tylko w kryteriach materialnych. Wskazywano na wielokulturowy charakter tych metropolii, chwalono panującą w nich otwartość i tolerancję, które składały się na poczucie zadowolenia $z$ życia $\mathrm{w}$ interesującym, zróżnicowanym środowisku i popychały do odważniejszych decyzji życiowych. Jednocześnie do poczucia pełni zadowolenia niezbędna była także możliwość podtrzymywania kontaktów z Polską, a często transnarodowośćc ${ }^{19}$, polegająca na budowaniu ponadgranicznych sieci powiązań na możliwie wielu płaszczyznach. Istotna okazywała się bliskość terytorialna Polski w przypadku Berlina oraz tanie i częste loty między Londynem a Polską. To poczucie bliskości niwelowało w dużym stopniu odczuwanie obcości za granicą. Dało możliwość realizacji indywidualnych strategii bez utraty istotnych wartości, takich jak rodzima kultura, więzi rodzinne czy przyjacielskie, co wpływało na dobre samopoczucie migrantów, utwierdzało ich w przekonaniu o słuszności decyzji o emigracji i tym samym o życiowym sukcesie.

Tak zwani migranci poakcesyjni znajdowali się od początku w nieporównywalnie korzystniejszej sytuacji prawnej od swoich poprzedników z końca XX w. Przede wszystkim mogli poszukiwać legalnej pracy. Faktem jest także, że wielu z nich już w momencie przyjazdu znało język niemiecki bądź angielski, co wcześniej zdarzało się stosunkowo rzadko. Migrantów charakteryzowało także inne niż we wcześniejszych falach nastawienie do społeczeństwa, pozbawione kompleksu pochodzenia z „gorszej, wschodniej części Europy".

Rozmówcy podkreślali, że jednym z najważniejszych czynników wpływających na pozostanie w Anglii była zdecydowana różnica między krajem osiedlenia a Polską w standardach w miejscu pracy. Według nich w Polsce nadal funkcjonował w relacjach pracowniczych nepotyzm, złe traktowanie podwładnych, zwłaszcza kobiet, niechęć do reformowania się i dokształcania, nieprzyjazna atmosfera dla przedsiębiorczości, brak egzekucji prawa zarówno w środowisku zakładu pracy, jak i szerzej w kraju. Bardzo często słychać było w czasie rozmów stwierdzenia podobne do wypowiedzi Polaka z Londynu:

W Polsce jest mniejsza konkurencja, ale w Anglii jest więcej możliwości, większa różnorodność, dużo mniejsza korupcja i kumoterstwo (R5_2015_Londyn).

W związku z tym - konkludował - obcym, ale pracowitym, wykształconym i utalentowanym ludziom dużo łatwiej i szybciej jest znaleźć dobrą pracę w zawodzie (w Anglii).

Podsumowując dotychczasową analizę, można stwierdzić, że respondenci z obu aglomeracji odczuwali sukces subiektywnie, w zależności od wcześniejszych oczekiwań

${ }^{19}$ Zagadnieniu transnarodowości Polaków na emigracji poświęcony będzie odrębny artykuł. 
i kapitału wyniesionego z domu. Niektórzy rozwinęli nawet światowe kariery, co można traktować jako sukces w znaczeniu obiektywnym. Przede wszystkim jednak każdy rodzaj sukcesu oparty był na zaspokojeniu potrzeby dobrostanu (well-being), zadowalającego standardu życia, w którym odczuwa się bezpieczeństwo, jasność i stałość przepisów prawnych, stabilizację zarobkową, możliwości edukacji dla każdego, pewność pracy i awansu, otwarty i szeroki dostęp do dóbr kultury, mediów, sportu, podróży.

Większość respondentów londyńskich nie była silnie związana z Polonią. Na ogół znali kilku Polaków w momencie przyjazdu, ale z racji znajomości angielskiego, zaprzyjaźniali się z osobami innych narodowości. Pracę często zdobywali w środowisku niezwiązanym $z$ własnym etnicznym środowiskiem, lecz typowo lokalnym lub multikulturowym. Uważali, że swój mini-sukces zawdzięczają faktowi, że żyją podobnie jak inni Brytyjczycy, nie stroniąc od kontaktów z nimi. Znali Polaków, ale poznawali ich nie przez organizacje, tylko poprzez pracę, sąsiedztwo i rodzinę. Sukces coraz częściej osiągany był w oderwaniu od środowiska polonijnego, w tak zwanej grupie rozproszonej.

Świadczył o tym przykład Polki, zakorzenionej w aglomeracji londyńskiej od trzydziestu lat, a od ponad dwudziestu posiadającej brytyjskie obywatelstwo. Była żoną Irlandczyka. Rozmówczyni nie miała wielu kontaktów z organizacjami polonijnymi. Utrzymywała natomiast stałą łączność ze swoją rodziną - Brytyjczykami polskiego pochodzenia, którzy należeli do emigracji powojennej, oraz z kilkoma polskimi znajomymi w Anglii.

Byłam rzucona od razu na głęboką wodę: oprócz moich kuzynów, których widywałam raz na parę tygodni, nie znałam żadnych Polaków. Na początku dzieliłam duży pokój w hostelu z dwiema dziewczynami - Australijką i Angielką. Musiałam od początku ze wszystkimi mówić po angielsku i się dosyć szybko osłuchałam. (...) Jedynych Polaków, jakich wtedy poznałam to przez moich kuzynów: jak robili jakieś party, to wtedy. Na co dzień nie przebywałam z Polakami. Natomiast moi kuzyni otoczeni byli samymi Polakami. Poza środowiskiem kuzynów poznałam tylko jedną osobę, moją przyjaciółkę Basię. I to była jedyna Polka, jaką poznałam bezpośrednio, bo tak to tylko przez kuzynów. Prawdę mówiąc, to nie miałam potrzeby kontaktowania się z Polonią. Ta Polonia wtedy [początek lat 80.] była inna niż teraz. (...) Nie integrowaliśmy się tak, jak w tej chwili integruje się Polonia z lat 80. z tymi, co teraz przyjeżdżają. (...) Trudno mi powiedzieć, dlaczego ta stara Polonia nie wchłaniała tych kolejnych Polaków przyjeżdżających. Nie wiem. Ale oni trochę na nas patrzyli z góry (śmiech) (R8_2015_Londyn).

W środowisku niemieckim polscy rozmówcy niezależnie od tego, czy przybywali pod koniec XX wieku, czy w ostatnich latach, utrzymywali kontakty z co najmniej kilkoma innymi osobami, które przyjechały z Polski. Faktem jest natomiast, iż obecnie wielkość kręgów znajomych nieco się zmniejszyła, w wyniku zmiany realiów, w których 
odbywają się migracje. Pod koniec XX wieku migranci częściej przyjeżdżali do Berlina w ramach sieci złożonej z rodziny i przyjaciól, która następnie zapewniała wsparcie, była niezwykle pomocna, a niekiedy nawet niezbędna w pierwszych krokach za granicą. Dziś migracje mają charakter zdecydowanie bardziej indywidualny, uniezależniony od powiązań. Nadal jednak z tego środowiska pochodzą najbliżsi przyjaciele respondentów. Jak twierdzili, we wzajemnych relacjach niezastąpiona była wspólnota przeżyć wyniesionych z kraju, ale liczyły się także język, wartości, podejście do rodziny, pracy, edukacji, tradycji, a nawet poczucie humoru. Polacy wskazywali na elementy, które na ogół leżą u podstaw bliskich więzi przyjacielskich, takie jak „odbieranie na tej samej fali”, podobne zainteresowania, poziom intelektualny. Nie były to zatem przypadkowo spotkane osoby, spełniały takie same warunki, jakie musiałyby spełnić także w Polsce. Żaden z respondentów nie ograniczał się jednak tylko do środowiska polskiego. Wśród znajomych berlińskich rozmówców wielu było Niemców i innych cudzoziemców mieszkających w Berlinie. Tego rodzaju wszechstronne więzi wpływały na poczucie sukcesu w sensie społecznym. Relacje z Polakami nie miały natomiast większego wpływu na sukces w sensie materialnym, odnoszony na ogół w oderwaniu od własnej grupy etnicznej, mimo iż działalność gospodarcza migrantów niekiedy związana była z obsługą tej grupy bądź z wykorzystaniem polskich pracowników. Jeśli chodzi o relacje z Niemcami - wręcz przeciwnie wiele $\mathrm{z}$ nich miało swój początek w pracy.

Londyńscy respondenci podkreślali interkulturowy i międzynarodowy przekrój ich środowiska towarzyskiego, sąsiedzkiego i zawodowego. W wielu przypadkach znajomi migranci przeważali liczebnie nad Polakami, mimo iż rzadko zaliczano ich do bliskich przyjaciół.

Rozmówcy z obu miast unikali natomiast szeroko rozumianej Polonii, zakładającej budowanie pewnej wspólnoty przez sam fakt bycia Polakiem: jej zorganizowanych działań mających na celu podtrzymywanie polskości. Badani wybierali bardziej indywidualne, spersonalizowane kontakty zarówno z krajem, jak i wybranymi rodakami mieszkającymi za granicą. Najczęściej obawiali się, że mogłaby się sprawdzić popularna wśród ogółu migrantów opinia, iż za granicą lepiej nie ufać Polakom, zdolnym do wielu krzywdzących działań wobec swojej grupy.

Nie oznacza to, że migranci nie korzystali z atrakcji kulturalnych organizowanych przez instytucje polonijne. Jednak wyjście na koncert, wystawę czy spotkanie literackie $\mathrm{w}$ jednym $\mathrm{z}$ centrów polonijnych traktowali podobnie jak uczestnictwo w angielskiej czy niemieckiej imprezie. Wśród naszych respondentów zaledwie kilku zadeklarowało, że regularnie utrzymują lub utrzymywali kontakt $\mathrm{z}$ organizacjami polonijnymi, a nawet aktywnie się w nich udzielali. W tej małej grupie część osób zbudowała swoją karierę na pracy w środowisku polonijnym, ale większa część mimo wszystko poza nim.

Ten aspekt badań pozwolił stwierdzić, że migranci, którzy luźno bądź wcale nie są związani ze strukturami organizacji polonijnych, szybciej integrują się i odnoszą sukces zarówno w sferze znajomości kodów kulturowych i społecznych, jak i w środowisku, 
w którym mieszkają, pracują i uczą się. Szczególnie dotyczy to młodych Polaków mieszkających w aglomeracjach miejskich.

Sukces migracyjny wynikał z kapitału, głównie kulturowego i społecznego, choć nie można w niektórych przypadkach zapominać także o materialnym, zgromadzonym jeszcze w kraju bądź zbudowanym na miejscu, w państwie przyjmującym. Można zauważyć pewną regułę, choć nie dotyczy ona wszystkich przypadków, że im bogatszy kapitał społeczno-kulturowy wyniesiony z kraju rodzinnego i środowiska domowego, tym lepszy start i integracja w nowym społeczeństwie, a co za tym idzie, poczucie sukcesu i satysfakcji.

\section{Podsumowanie}

$\mathrm{Na}$ koniec chciałabym podkreślić, że do badań wybrana została specyficzna grupa ludzi sukcesu, co nie oznacza, iż życie na emigracji, czy to czasowej, czy długoterminowej, jak i tej z założeniem stałego osiedlenia, nie wiąże się z problemami związanymi $\mathrm{z}$ adaptacją $\mathrm{i}$ integracją. Także ludzie $\mathrm{z}$ grona naszych rozmówców na co dzień borykali się $\mathrm{z}$ poczuciem niedostosowania $\mathrm{w}$ niektórych sytuacjach, problemami językowymi, często psychologicznymi, z brakiem wsparcia lub chociażby obecności w trudnych chwilach rodziny lub przyjaciół, nieznajomością określonych kodów kulturowych, nierozumieniem niuansów $\mathrm{w}$ relacjach interpersonalnych, $\mathrm{z}$ rozpoznaniem miasta na tyle dobrym, by czuć się w nim jak u siebie, wreszcie z pierwotnie ograniczonym zasobem finansowym. Większości z nich nie ominęły trudności charakterystyczne szczególnie dla początkowego okresu pobytu za granicą, jak choćby problemy mieszkaniowe: konieczność wynajmowania pokoju w mieszkaniu $z$ innymi ludźmi, drożyzna. Także miejsce pracy - przynajmniej na początku - było elementem stresu dla większości nowoprzybyłych: praca w nieznanym otoczeniu społecznym, szybkie przyuczanie się do odmiennych niż dotąd obowiązków zawodowych, wykonywanych w całkowicie innym niż polski systemie pracy, relacji zawodowych, ubezpieczeń, wynagrodzeń, wymogów i zasad. Naszych rozmówców wyróżniała jednak umiejętność przezwyciężenia wszystkich lub przynajmniej większości z tych trudności, będąca swoistym sukcesem.

Integracja to najważniejszy sukces, który każdy z respondentów osiągnął, zarówno w kategoriach subiektywnych, jak i obiektywnych. Osiągnięcie dobrostanu to kolejna ważna cecha sukcesu polskiego migranta. Trzecią z nich jest życie w poczuciu stabilizacji społeczno-administracyjnej w krajach zapewniających stałe reguły ładu państwowego i społecznego, nakierowanego na obywatela, gdzie zasady demokratyczne i pracownicze są przestrzegane. Także odpowiedni poziom zarobków, który gwarantuje stabilność życia materialnego oraz poczucie możliwości realizacji planów, jak i zagwarantowania przyszłości, to kolejna ważna cecha sukcesu. Wreszcie, efekty głębokiej integracji, takie jak zaangażowanie w lokalną działalność społeczną, związkową, obywatelską, na rzecz dzielnicy lub miasta, w którym się mieszka, czy budowanie stowarzyszeń, organizacji, a nawet partii, to kolejne przejawy sukcesu na emigracji. Należy wymienić również 
możliwość zapewnienia dzieciom awansu społecznego i ekonomicznego o poziom wyższy niż własny, co w wielu przypadkach w Polsce nie byłoby możliwe. Na końcu: poczucie nieograniczonej mobilności, podróżowanie oraz - co ważniejsze - możliwość życia w dwóch i więcej kontekstach kulturowych i społecznych, w dwóch krajach, w transnarodowym systemie - to także ważne elementy nowego stylu życia i postrzegania osobistego dobrostanu i szczęścia.

Z przytoczonych przykładów z Berlina i Londynu można wyciągnąć wnioski, że migracje poakcesyjne młodych i wykształconych ludzi nie będą słabły. Polacy zdają sobie sprawę z tego, że wyjeżdżając w krótkim czasie mogą zaspokoić swoje oczekiwania, wysokie aspiracje, osiągnąć zachodni standard życia i realizować swoje cele. Nasi respondenci - porównując swoje życie do życia rodziny starszego pokolenia czy znajomych mieszkających w Polsce - zauważają własne możliwości szybkiego awansu społecznego i zawodowego. Jednocześnie utrzymywanie stałych związków z Polską, takich jak uczestnictwo w życiu politycznym, śledzenie wydarzeń, czytanie prasy, regularne odwiedziny w kraju, w dobie taniego transportu i Internetu nie stanowi przeszkody. Sprawia, że tęsknota za ojczyzną jest zminimalizowana, ledwie odczuwana. A taki komfort psychiczny sprzyja integracji z nowym krajem. Życie w dużej aglomeracji daje migrantom ogromne możliwości rozwoju oraz poczucie, że wszędzie sobie poradzą, wszędzie mogą żyć, ale żyją tam, gdzie chcą, a nie tam, gdzie przyszło im się urodzić. W ich opinii człowiek przebywający na emigracji osiąga sukces, gdy realizują się jego oczekiwania, gdy zachowana jest równowaga między pracą a życiem prywatnym oraz kiedy odczuwane jest poczucie dobrostanu i zadowolenia $\mathrm{z}$ życia. To jest ich recepta na sukces.

\section{Wykaz respondentów, których wypowiedzi wykorzystano w tekście:}

Berlin: M1_Berlin, M2_Berlin, M3_Berlin, M5_Berlin, K1_Berlin, K2_Berlin, K3_Berlin, K4_Berlin, K5_Berlin, K7_Berlin, K8_Berlin, K9_Berlin.

Londyn: R1_2015_Londyn, R2_2015_Londyn, R3_2015_Londyn, R4_2015_Londyn, R5_2015_Londyn, R7_2015_Londyn, R8_2015_Londyn, R9_2015_Londyn, R11_2015_ Londyn, R12_2015_Londyn, R1_2017_Londyn, R7_2017_Londyn.

\section{Bibliografia ${ }^{20}$}

Bartram D. 2013, Happiness and 'economic migration': A comparison of Eastern European migrants and stayers, „Migration Studies”, nr 1(2), s. 156-175.

Brannen J., Mooney A., Wigfall V. and Parutis V. 2014, Fatherhood and Transmission in the Context of Migration: An Irish and a Polish Case, „International Migration”, nr 52, s. 165-177.

Doroszewski W. (red.) 2016, Sukces, [w:] Stownik Jezzyka Polskiego, PWN, Warszawa, http://sjp. pwn.p1/szukaj/sukces.html, dostęp: 15.11.2016.

${ }^{20}$ Bibliografia metodologiczna i teoretyczna została zamieszczona w artykule Agnieszki Szczepaniak-Kroll $\mathrm{w}$ niniejszym tomie JUE. 
Fischer E.F. 2014, Good Life: Aspiration, Dignity and the Anthropology of Well Being, Stanford University Press, Stanford.

Horolets A. 2018, On Holiday? Polish Migrants Visit Their Families in Poland, [w:] M. Ślusarczyk, P. Pustułka, J. Struzik (red.), Contemporary Migrant Families: Actors and Issues, Cambridge Scholars Publishers, Newcastle upon Tyne, s.117-136.

Lofgren O. 2002, On Holiday: The History of Vacationing, University of California Press.

London Datastore, https://data.london.gov.uk/, dostęp: 04.05.2020.

Mayor of London 2010, An evidence base on migration and integration in London, ESRC Centre on Migration, Policy and Society, University of Oxford, London, https://www.london.gov. $\mathrm{uk} /$ sites/default/files/an_evidence_base_on_migration_and_integration_in_london.pdf, dostęp: 01.04.2020.

Sobczyk J. R. 2009, Aksjologia sukcesu - uwarunkowania pomiaru (miary i oceny), „Prace i Materiały Wydziału Zarządzania Uniwersytetu Gdańskiego: Sukces organizacji. Istota, pomiar, uwarunkowania”, nr 7 (2/1), s. 81-90.

Autorka:

dr Anna Szymoszyn

Instytut Archeologii i Etnologii, Polska Akademia Nauk

ul. Rubież 46, 61-612 Poznań

e-mail: etnopan@iaepan.poznan.pl 